\title{
PENGGUNAAN METODE POSTER SESSION UNTUK MENINGKATKAN KETERAMPILAN BERCERITA MAHASISWA
}

\author{
Tyasmiarni Citrawati ${ }^{1}$, Agung Setyawan ${ }^{2}$, Gilang Maulana Jamaludin ${ }^{3}$, Luqman Hakim ${ }^{4}$ \\ ${ }^{1,2,4)}$ Universitas Trunojoyo Madura \\ ${ }^{3)}$ Universitas Majalengka
}

\begin{abstract}
This study aims to improve students' storytelling skills through the Poster Session method. This quantitative experimental research uses the Quasi-Experimental method with a nonequivalent control group design. The sample of this study consisted of 80 students from 200 semester IV student populations. Data collection techniques are done by the method of test and non-test. The test instrument was in the form of a story skills assessment sheet. Also, questionnaires and observation sheets were used for non-test instruments. Testing the validity, instrument reliability, normality test, homogeneity test, linear test, simple linear regression test, t-test significant, gain test. Processed with the help of the Excel 2013 program. The results showed the average value of the experimental class posttest was 89.4 and the average posttest value of the control class was only 68.7 and the significance test was obtained with a count of 7.423 then Ho is rejected so there is a significant effect. Based on the results of the student response questionnaire, the average score obtained by students 79.74 from the maximum score of 80 , this shows the response of students to learning the Poster Session method is high. So that shows that the Poster Session method influences improving students' storytelling skills.
\end{abstract}

Keywords: Method, Poster Session, storytelling skills

\begin{abstract}
ABSTRAK
Penelitian ini bertujuan untuk meningkatkan keterampilan bercerita mahasiswa melalui metode Poster Session. Penelitian kuantitatif eksperimen ini menggunakan metode Quasi Experimental dengan rancangan nonequivalent control grup design. Sampel penelitian ini terdiri dari 80 mahasiswa dari 200 populasi mahasiswa semester IV. Teknik pengumpulan data dilakukan dengan metode tes, dan non tes. Instrumen tes berupa lembar penilaian keterampilan bercerita. Selain itu juga angket dan lembar observasi digunakan untuk instrumen non tes. Pengujian validitas, reliabilitas instrumen, uji normalitas, uji homogenitas, uji linier, uji regresi linier sederhana, uji signifikan t, uji gain. Diolah dengan bantuan program Excel 2013. Hasil penelitian menunjukkan rata-rata nilai posttest kelas eksperimen sebesar 89,4 dan rata-rata nilai posttest kelas kontrol hanya 68,7 dan uji signifikasi diperoleh nilai dengan thitung sebesar 7,423 maka Ho ditolak sehingga terdapat pengaruh yang signifikan. Berdasarkan hasil angket respon mahasiswa maka rata-rata skor yang diperoleh mahasiswa 79,74 dari sekor maksimal 80, ini menunjukkan respon mahasiswa terhadap pembelajaran metode Poster Session tinggi. Sehingga menunjukkan bahwa metode Poster Session memiliki pengaruh dalam meningkatkan keterampilan bercerita mahasiswa.
\end{abstract}

Kata Kunci: Persepsi Guru, Media Pembelajaran.

\footnotetext{
${ }^{1)}$ Korespondensi : Tyasmiarni Citrawayi, Universitas Trunojoyo Madura, Email: tyasmiarni.citrawati@trunojoyo.ac.id

${ }^{2)}$ Agung Setyawan, Universitas Trunojoyo Madura, Email penulis agungtyas77@gmail.com
} 
PENDAHULUAN

Beberapa prinsip dalam pelaksanaan pembelajaran parsipatif: Pertama, berdasarkan kebutuhan belajar (Learning needs based) sebagai keinginan maupun kehendak yang dirasakan oleh peserta didik. Kedua, berorientasi kepada tujuan kegiatan belajar (Learning goals and objectives oriented). Ketiga, berpusat kepada peserta didik (Participand centerd). Keempat, belajar berdasarkan pengalaman (Experiental Leraning), bahwa kegiatan belajar harus selalu dihubungkan oleh pengalaman siswa (Mulyasa, 2013).

Kurikulum KKNI mengarahkan mahasiswa untuk berperan serta aktif dalam setiap mata kuliah tidak terkeculai pada pembelajaran bagasa dan sastra Indonesia. Permasalahan yang ditemukan peneliti dilapangan masih kurangnya peran aktif mahasiswa dalam pembelajaran terutama pada keterampilan bercerita. Mata kuliah ini mengharapkan mahasiswa lebih aktif berkomunikasi dalam bentuk keterampilan bercerita. $65 \%$ mahasiswa pada kelas yang di observasi peneliti masih kurang keterampilan berceritanya. Diperlukannya formula metode yang tepat dan sesuai untuk menyelesaikan permasalahan tersebut sehingga keterampilan bercerita

mahasiswa meningkat.

Menciptakan mahasiswa yang aktif dan partisipatif dibutuhkan metode pembelajaran yang bervariasai dalam proses pembelajaran (Faturrahman, 2012; Hamzah, 2013; Kadir dan Asrohah, 2014). Salah satu metode yang dapat digunakan untuk menciptakan pembelajaran yang aktif dan partisipatif adalah metode Poster Session, karena metode Poster Session mampu membuat mahasiswa aktif dan kreatif karena metode ini menuntut mahasiswa mampu mengemukakan pendapatnya, merangkum materi yang dijelaskan dan mampu membuat poster sendiri dari materi yang diperoleh. Dengan demikian mahasiswa mampu melakukan kegiatan yang beragam untuk mengembangkan ketrampilan, sikap, dan pemahaman karena mahasiswa belajar sambil bekerja. Metode Poster Session dapat dipadukan pada mata kuliah kajian bahasa dan sastra indonesia. Materi ini dipilih karena selain metode Poster Session membutuhkan materi yang bergambar metode Poster Session juga dapat merangsang mahasiswa untuk aktif dan mengimplementasikan materi yang diajarkan melalui poster yang digambar mahasiswa itu sendiri sehingga mudah untuk dipahami. Beberapa kelebihan dari 
metode Poster Session adalah menjadikan peserta didik siap dalam memulai pelajaran, karena peserta didik belajar terlebih dahulu dan merangsang peserta didik untuk aktif bertanya dan mencari informasi (Iswati, 2012).Penelitian ini bertujuan utama untuk meningkatkan keterampilan bercerita mahasiswa melalui metode Poster Session.

\section{METODE PENELITIAN}

Penelitian ini menggunakan metode eksperimen denggan Quasi Eksperimntal yang dilaksanakan di Universitas Trunojoyo Madura. Populasi yang digunakan pada penelitian ini adalah seluruh mahasiswa semester IV berjumlah 200 mahasiswa. Sampel pada penelitian ini adalah ada 80 mahasiswa yang dibagi ke dalam 2 kelas 4A dan 4B untuk kelas eksperimen. Peneliti juga menggunakan kelas kontrol 4C dan 4D dengan jumlah yang sama.Instrumen pengumpulan data dalam penelitian ini menggunakan Tes keterampilan bercerita, non tes berupa angket, dan lembar observasi. Lembar tes digunakan untuk mengukur keterampilan berceritayang diberikan ketika pretest dan posttest. Dua instrumen tes yang serupa tapi tidak sama yang diujikan pada kelas eksperimen dan kelas kelas kontrol. Lembar observasi keterlaksanaan pembelajaran memodifikasi dari (Sudjoko, 2010; Lestari, 2015) dan observasi kegiatan mahasiswa selama kegiatan pembelajaran mengadopsi dari (Kunandar, 2011). Sedangkan, respon mahasiswa dilakukan untuk mengetahui seberapa besar respon mahasiswa tertarik pada pembelajaran menggunakan metode Poster Session terhadap keterampilan bercerita.

Teknik analisis data yang digunakan dalam penelitian ini dibagi menjadi lima macam yaitu: validasi ahli terhadap instrumen penelitian, analisis data uji coba instrumen tes keterampilan bercerita, analisis data instrumen lembar observasi, analisis data instrumen angket respon keterampilan bercerita, dan analisis data hasil keterampilan bercerita. Analisis data validasi ahli terhadap instrumen penelitian ini dilakukan pada instrumen dan perangkat pembelajaran. Analisis ini dilakukan untuk mengetahui kelayakan instrumen penelitian sebelum digunakan dalam penelitian. Analisis data instrumen tes keterampilan bercerita meliputi uji validitas dan uji reliabilitas. Data hasil tes keterampilan bercerita yang dianalisis adalah data hasil uji coba soal. Sedangkan pengujian yang dilakukan dalam analisis hasil tes keterampilan bercerita meliputi uji normalitas, uji homogenitas, uji 
linieritas, uji regresi linier sederhana, dan uji signifikansi (uji-t). Data yang digunakan untuk analisis hasil tes keterampilan bercerita adalah data pretest dan posttest. Untuk analisis aktivitas dilakukan untuk mengetahui aktivitas dosen dan mahasiswa ketika pembelajaran. Sedangkan analisis angket respon mahasiswa dilakukan untuk melihat seberapa besar respon mahasiswa tertarik pada pembelajaran metode Poster Session.

\section{HASIL DAN PEMBAHASAN}

Sebelum instrumen tes

keterampilan bercerita digunakan maka perlu di uji cobakan untuk mengetahui kevalidan dari soal. Analisis data instrumen tes keterampilan bercerita dilakukan pada data hasil uji coba soal yang dilakukan pada mahasiswa PGSD kelas 4EUniversitas Trunojoyo Madura. Perolehan data tes keterampilan bercerita pada tes uji coba instrumen penelitian di hitung menggunakan uji validitas dan uji reliabilitas. Untuk menguji validitas hasil uji coba tes keterampilan bercerita tersebut menggunakan rumus korelasi Product Moment dari kedua tipe soal A dan B yakni untuk tipe soal A diperoleh 21 soal valid dan 4 soal tidak valid. Sedangkan pada tipe soal B diperoleh 21 soal valid dan 4 soal tidak valid. Soal yang digunakan hanya 20 soal dan soal nomor 25 tipe A dan soal nomor 23 tipe B tidak digunakan karena untuk menyeimbangkan dan memiliki korelasi yang lebih rendah. Selanjutnya Soal tersebut kemudian di uji reliabilitas menggunakan rumus Alpha Cronbach karena soal yang diujikan dalam bentuk skala keterampilan bercerita.

Instrumen soal yang diuji cobakan kemudian dapat digunakan untuk mengukur keterampilan bercerita. Soal tersebut digunakan untuk melakukan pretest dan postest. Data nilai pretest dan posttest mahasiswa yang telah diolah dapat dilihat pada tabel berikut ini:

Tabel 1. Tabel Hasil Uji Normalitas Dan Homogenitas

\begin{tabular}{|l|l|l|l|l|}
\hline \multirow{2}{*}{ Keterangan Data } & \multicolumn{2}{|l|}{ Kelas Eksperimen } & \multicolumn{2}{l|}{ Kelas Kontrol } \\
\cline { 2 - 5 } & Pretest & Posttest & Pretest & Posttest \\
\hline Nilai Rata-rata & 62,8 & 89,4 & 61,1 & 68,7 \\
\hline Uji Normalitas (Dhitung) & 0,108 & 0,196 & 0,160 & 0,142 \\
\hline Uji Homogenitas (F Fitung) $^{\mid 3} 0,403$ & & \\
\hline
\end{tabular}


Tabel di atas diketahui bahwa: (1) Rata-rata nilai pretest mahasiswa kelas eksperimen adalah 62,8 dan Rata-rata nilai posttest mahasiswa kelas eksperimen adalah 89,4, dan Rata-rata nilai pretest mahasiswa kelas kontrol adalah 61,1 dan rata-rata nilai posttest mahasiswa kelas kontrol adalah 68,7. Dengan demikian, hasil tes keterampilan berceritamahasiswa menggunakan metode Poster Session pada kelas eksperimen lebih tinggi dibanding hasil tes keterampilan bercerita kelas kontrol.

Mengetahui pengaruh penerapan metode Poster Session terhadap keterampilan bercerita mahasiswaPGSD Universitas Trunojoyo Madura, maka data hasi pretes dan data posttest kedua kelas dianalisis menggunakan statistik parametris. Agar data setiap variabel dapat dianalisis, maka data harus berdistribusi normal. Setelah kedua kelas sampel dinyatakan berdistribusi normal, maka asumsi selanjutnya yang harus dipenuhi adalah homoginitas.

Data yang diperoleh dapat diketahui bahwa antara nilai D1 dan D2 lebih besar nilai $\mathrm{D} 1$, sehingga nilai $\mathrm{D}_{\text {hitung }}$ adalah 0,108. sedangkan $\mathrm{D}_{\text {tabel }}$ diperoleh dari $\quad \mathrm{D}(\mathrm{a}, \mathrm{n}-1)=\mathrm{D}(0,05,34)$. Nilai
$\mathrm{D}(0,05,34)$. Pada tabel kolmogorov smirnov bernilai 0,2047. Kemudian $D_{\text {hitung }}$ dan $\mathrm{D}_{\text {tabel }}$ dibandingkan dan hasilnya $D_{\text {hitung }}=0,108 \leq D_{\text {tabel }}=0,2047$ maka Ho diterima dan data nilai Pre-test kelompok eksperimen berdistribusi normal. Pada uji normalitas pada Post-test kelompok eksperimen diperoleh nilai D1 > D2 maka $D_{\text {hitung }}=0.196$, sehingga $D_{\text {hitung }}=0,196 \leq$ $\mathrm{D}_{\text {tabel }}$ 0,2047. Kesimpulan yang diperoleh untuk uji normalitas pada nilai Post-test eksperimen berdistribusi normal.

Untuk hasil uji normalitas kelompok kontrol adalah menghasilkan D1 > D2, dengan demikian nilai $\mathrm{D}_{\text {hitung }}$ 1,60. Kemudian $D_{\text {hitung dibandingkan }}$ dengan hasil $\mathrm{D}_{\text {tabel }}$ dan menghasilkan $\mathrm{D}_{\text {hitung }} 0,16 \leq \mathrm{D}_{\text {tabe }} \mathrm{l}=2$ 2047. Dari kaidah tersebut dapat diambil keputusan bahwa data nilai pre-test kontrol berdistribusi normal. Sedangkan pada nilai post-test kontrol diperoleh nilai $\mathrm{D} 1>\mathrm{D} 2=0,142$, sehingga $D_{\text {hitung }}=0,142 \leq 2047$. Jadi untuk uji normalitas pada nilai post-test kelompok kontrol adalah berdistribusi normal. Kesimpulan yang diperoleh dari uji normalitas ini bahwa nilai pre-test dan post-test kelompok eksperimen dan nilai pre-test dan nilai post-test kelompok kontrol berdistribusi normal.

Analisis peningkatan kemudian dilakukan dengan menggunakan uji 
regresi linier sederhana. Sebelum didapat $F_{\text {tabel. }}$ Sehingga $F_{\text {hitung }}=70,94>\mathrm{F}$ dilakukan uji regresi linier sedrehana tabel $=4,13$ maka dapat disimpulkan bahwa terlebih dahulu dilakukan uji prasyarat Ho ditolak artinya data dari kelompok berupa uji linieritas. Uji linieritas eksperimen berpola linier. Oleh karena dilakukan dengan melakukan analisis itu, analisis pengaruh dapat dilakukan terhadap hasil pretest dan posttest pada kelas eksperimen. Hasil uji linieritas diperoleh nilai $\mathrm{F}_{\text {hitung }}=70,94$ dengan taraf signifikan $(\alpha)=0,05$ dengan interpolasi dengan menggunakan uji regresi linier sederhana. Adapun hasil analisis uji regresi linier sederhana disajikan dalam tabel berikut:

Tabel 2.Uji Regresi Linier Sederhana

\begin{tabular}{|l|l|}
\hline \multicolumn{1}{|c|}{ Data } & Nilai \\
\hline Nilai Konstanta b & 0,747 \\
\hline Nilai Konstanta a & 23 \\
\hline Rata - rata X & 62,8 \\
\hline Rata - rata Y & 69,4 \\
\hline Nilai Korelasi ${ }^{\circledR}$ & $\mathrm{Y}=\mathrm{a}+\mathrm{bX}$ \\
& $\mathrm{Y}=23+0,747 \mathrm{X}$ \\
\hline Fhitung & 71 \\
\hline Ftabel & 4.13 \\
\hline
\end{tabular}

Hasil uji regresi linier sederhana konstanta a sebesar 23 yang berarti apabila tanpa adanya proses pembelajaran menggunakan metode Poster Session (X), maka nilai tes keterampilan berceritamahasiswa 23 . Koefisien regresi $\mathrm{b}=0,747$ mengindikasikan besaran penambahan nilai tes keterampilan berceritamahasiswa PGSD Universitas Trunojoyo Madura. Untuk setiap penambahan penerapan pembelajaran metode Poster Session. Persamaan regresi $\mathrm{Y}=\mathrm{a}+\mathrm{b} \cdot \mathrm{X}$ digunakan sebagai dasar acuan untuk memprediksi tes keterampilan bercerita peduli lingkunan yang dipengaruhi metode Poster Session. Persamaan uji regresi diperoleh $\mathrm{Y}=23+$ 0,747. X sedangkan untuk nilai korelasi ( r) diperoleh 23,75 . Hal ini menunjukkan bahwa metode Poster Session mampu 
meningkatkan keterampilan bercerita mahasiswa.

Uji signifikan dilakukan untuk menguji kevalidan persamaan regresi. Berdasarkan uji signifikan yang telah dilakukan diperoleh nilai $\mathrm{t}_{\text {hitung }}=71$. Dari tabel distibusi t dengan taraf $(\alpha)=0,05$ maka didapatkan $t_{\text {tabel }}=4.13$. berdasarkan kaidah pengujian nilai thitung dan $t_{\text {tabel }}$ yang diperoleh dapat disimpulkan bahwa $t_{\text {hitung }}>$

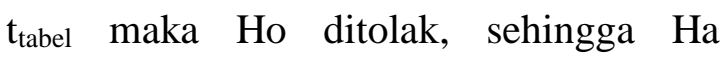
diterima. Jadi dapat disimpulkan bahwa terdapat pengaruh signifikan antara metode Poster Session dengan keterampilan berceritamahasiswa PGSD Universitas Trunojoyo Madura.

Uji gain ternormalisasi dilakukan setelah hasil uji hipotesis menunjukkan pengaruh yang signifikan. Uji gain ternormalisasi bertujuan untuk mengetahui hasil peningkatan awal hingga akhir apakah terdaat perbedaan peningkatan nilai mahasiswa secara individu. Berdasarkan hasil yang diperoleh dari uji gain ternormalisasi dapat disimpulkan bahwa ada peningkatan dari kedua kelas akan tetapi kelas ekserimen lebih besar peningkatannya rata-rata yakni 0,45 untuk kelas eksperimen dengan kategori sedang dan 0,38 untuk kelas kontrol dengan kategori sedang.
Dari 20 soal yang diberikan untuk 80mahasiswa kelas eksperimen rata-rata dari semua mahasiswa $88 \%$ merespon bahwa pengunaan metode Poster Session berkatagori sangat baik. Ini terbukti dari 20 pertanyaan dan skor maksimal 80 ratarata mahasiswa memperoleh nilai 70,7. Sehingga penggunaan Metode Poster Session terhadap keterampilan berceritamahasiswa oleh peneliti bersifat positif.

Hasil observasi keterlaksanaan pembelajaran yang dilakukan oleh dosen atau aktivitas dosen mencakup 28 indikator yang dimodifikasi dari (Lestari, 2015). Pada pertemuan pertama dan pertemuan kedua mengalami peningkatan. Pada pertemuan pertama memperoleh skor 76 denggan rata-rata skor 3,45 berkategori baik dan pertemuan kedua memperoleh skor 80 dengan rata-rata skor 3,63 dengan kategori sangat baik.

Instrumen yang digunakan untuk mengukur hasil belajar dalam penelitian ini adalah tes keterampilan bercerita berupa Pretest untuk mengetahui kemampuan awal mahasiswa sebelum diberikan perlakuan pembelajaran dengan menerapkan metode Poster Session dan untuk mengukur kemampuan mahasiswa setelah diberikan perlakuan atau penerapan metode Poster Session terhadap 
keterampilan bercerita menggunakan posttest.

Berdasarkan data dari uji signifikan atau uji $\mathrm{t}$ diperoleh nilai thitung $=$ 8,423 dan $t_{\text {tabel }}=1,787$. Berdasarkan kaidah pengujian $t_{\text {hitung }}=8,423>\mathrm{t}_{\text {tabel }}=$ 1,787 maka Ho ditolak sehingga terdapat pengaruh yang signifikan metode Poster Session dengan keterampilan berceritamahasiswa PGSD Universitas Trunojoyo Madura.

Hasil penelitian yang dilakukan menunjukkan bahwa pembelajaran menggunakan metode Poster Session memberikan pengaruh positif terhadap keterampilan berceritamahasiswa. Hal ini berarti hasil nilai Posttest mahasiswa menunjukkan hasil penguasaan yang dicapai mahasiswa sangat optimal setelah pembelajaran menggunakan metode Poster Session.

Hasil angket respon mahasiswa menunjukkan bahwa rata-rata dari semua mahasiswa $88 \%$ merespon bahwa penggunaan metode Poster Session berkategori sangat baik. Ini terbukti dari 20 pertanyaan dan skor maksimal 80 ratarata mahasiswa memperoleh nilai 70,7. Sehingga penggunaan Metode Poster Session terhadap keterampilan berceritamahasiswa bernilai positif.

SIMPULAN DAN SARAN

\section{Simpulan}

Berdasarkan hasil penelitian yang telah dilakukan dapat disimpulakan bahwa: (1) Terdapat pengaruh peningkatan yang signifikan metode Poster Session dengan keterampilan bercerita mahasiswa PGSD Universitas Trunojoyo Madura. Hal ini dibuktikan dengan rata-rata nilai posttest kelas eksperimen sebesar 89,4 dan rata-rata nilai posttest kelas kontrol hanya 68,7. Berdasarkan data dari uji signifikan atau uji $\mathrm{t}$ diperoleh nilai $\mathrm{t}_{\text {hitung }}=8,423$ dan $\mathrm{t}_{\text {tabel }}$ $=1,787$. Berdasarkan kaidah pengujian $\mathrm{t}_{\text {hitung }}=8,423>\mathrm{t}_{\text {tabel }}=1,787$ maka Ho ditolak. Sehingga adanya pengaruh pembelajaran dengan menerapkan metode Poster Session terhadap keterampilan bercerita mahasiswa. (2) Respon mahasiswa terhadap penerapan metode Poster Session secara keseluruhan maka rata-rata skor yang diperoleh mahasiswa adalah 70,74 dari skor maksimal 80 dalam kriteria "sangat baik" Maka persentase angket sebagai respon mahasiswa terhadap pembelajaran menggunakan metode Poster Session terhadap keterampilan bercerita sangatlah baik artinya mahasiswa tertarik dengan pembelajaran menggunakan metode Poster Session. (3) Berdasarkan hasil observasi aktivitas mahasiswa pada 
pertemuan awal memperoleh nilai ratarata 86,5 dan pada pertemuan akhir memperoleh nilai rata-rata 90 keduanya memiliki kategori sangat baik. Terjadi peningkatan nilai sebesar 3,5, sehingga dari hasil yang telah diperoleh menunjukkan bahwa kegiatan pembelajaran menggunakan metode Poster Session dapat terlaksana dengan baik dan membuat mahasiswa tertarik dalam pembelajaran.

\section{Saran}

Metode Poster Session dapat diaplikasikan ke matakuliah yang berbeda serta dapat digunakan untuk mengukur keterampilan lainnya

\section{DAFTAR PUSTAKA}

Faturrahman, dkk. 2012. Pengantar Pendidikan. Jakarta: Prestasi Pustakarya

Hamzah, S. 2013. Pendidikan Lingkungan (Sekelumit wawasan Pengantar). Bandung : Refika Aditama

Iswati. 2012. "Penerapan Metode Pembelajaran Poster Session pada mata pelajaran MTK." Skripsi. Semarang: Fakultas Ilmu Kedosenan dan Pendidikan. Univ.Muhammadiyah Semarang

Kadir dan Asrohah. 2014. Pembelajaran tematik. Depok : PT Raja Grafindo Persada

Kunandar. 2011.Dosen Profesional Implementasi Kurikulum Tingkat Satuan Pendidikan dan Sukses Dalam Sertifikasi Dosen. Jakarta: PT.Raja Grafindo Persada

Lestari, E. 2015. "Pengaruh Pendekatan SCIENTIFIC Terhadap Hasil Belajar Matematika Siswa Kelas III Pada Materi Menyelesaikan Masalah Keliling Dan Luas Bangun Datar Di SDN Bancaran 3 Bangkalan.” Skripsi. Bangkalan: Fakultas Ilmu Pendidikan. Univ Trunojoyo Madura.

Mulyasa. 2014. Pengembangan dan Implementasi Kurikulum 2013. Bandung: PT Rosdakarya

Sudjoko, dkk. 2010. Pendidikan Lingkungan Hidup. Jakarta : Universitas Terbuka. 